\title{
PENGARUH KONSENTRASI GARAM DAN LAMA FERMENTASI TERHADAP KADAR HISTAMIN PEDA IKAN KEMBUNG PEREMPUAN (Rastrelinger nelectus)
}

\author{
Juharni \\ Staf Pengajar FPIK UNKHAIR-Ternate, e-mail: -
}

\begin{abstract}
ABSTRAK
Peda merupakan salah satu produk hasil pengolahan secara tradisional yang digolongkan sebagai ikan asin basah. Perinsip pengolahannya adalah dengan memberikan sejumlah garam dengan konsentrasi tertentu pada ikan segar, kemudian difermentasi, dijemur dan difermentasi kembali sampai tercium aroma khas ikan peda. Tujuan penelitian ini untuk mrngetahui pengaruh konsentrasi garam dan lama fermentasi terhadap kandungan histamine peda, Penelitian ini dilakukan dalam dua tahap yaitu penelitian pendahuluan yang dimaksudkan untuk mengetahui proses pengolahan peda secara tradisional dan penelitian utama, dimana dilakukan pembuatan peda secara laboratoris dengan metode modifikasi dan hasil survey lapang dan kaji pustaka. Produk yang dihasilkan selanjutnya dianalisa kadar histamine, kadar air, dan pHnya, dengan parameter perlakuan konsentrasi garam $20 \%$ dan $30 \%$ dengan lama masing-masing fermentasi 5 - 7 hari. Hasil analisa produk peda tersebut menunjukkan bahwa dengan konsentrasi garam 30\% dengan lama fermentasi 5 hari memiliki kadar histamine $(29,65 \mathrm{mg} / 100 \mathrm{gr})$, kadar air $(53,44 \%)$, dan $\mathrm{pH}(5,4)$ yang lebih rendah dibandingkan dengan perlakuan konsentrasi garam $20 \%$ dengan fermentasi 5 hari dan 7 hari.
\end{abstract}

Kata Kunci: Peda, fermentasi, kembung

\section{PENDAHULUAN}

\subsection{Latar Belakang}

Indonesia merupakan negara yang memiliki wilayah perairan cukup luas dan mengandung kekayaan laut yang sangat besar. Dengan kekayaan laut yang dimilikinya mengandung perhatian banyak orang untuk memanfaatkannya termasuk pemerintah dan masyarakat. Tindak lanjut dari perhatian pemerintah yaitu meningkatkan kegiatan pembinaan pada masyarakat pantai baik berupa penyuluhan maupun kegiatan penelitian dari berbagai pusat studi dan pembangunan masyarakat pantai

Hasil utama yang disukai oleh masyarakatsebagai sumber pangan dari laut adalah ikan. Berbagai jenis pengolahan perikanan telah dikenal dan dimanfaatkan oleh masyarakat sebagai bahan pangan. Salah satu hasil pengolahan tradisional yang cukup digemari oleh masyarakat adalah "Peda".

Peda merupakan salah satu produk hasil fermentasi yang digolongkan sebagai ikan asin basah dan sangat disukai oleh masyarakat karena memiliki flavor dan aroma yan khas dan daya awet yang cukup lama.

Masalah yang dihadapai pada pembuatan peda adalah timbulnya rasa gatal setelah mengkonsumsi peda. Keracunan terjadi jika seseorang mengkonsumsi makanan yang mengandung histamin.

Histamin merupakan senyawa biogenik amin yang terbentuk akibat proses dekarboksilasi asam amino histidin yang terdapat pada tubuh ikan. Ada dua macam histidin dalam daging ikan, yaitu histidin bebas dan histidin terikat. Hanya histidin bebas yang dpat mengalami dekarboksilasi menjdi asam amino. Kadar histamin yang 


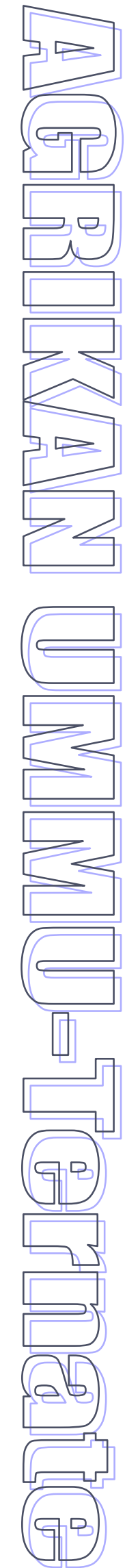

tinggi dan tidak mampu ditoleransi oleh tubuh dapat menimbulkan keracunan.

Gejala keracunan yang disebabkan oleh histamin umumnya dimulai 1 jam setelah masuknya toksin. Gejala tersebut berupa mual, muntah, perut mengejang, diare dan sakit kepala. Gejala lain yang timbul akibat racun ini yaitu gatal-gatal, kulit berbintik-bintik merah yang disertai demam (Kim et al., 2002).

Ikan yang banyak mengandung histamin adalah golongan scombroidae, karena pada jaringan daging merahnya banyak mengandung asam amino histidin bebas. Tuna, tongkol, tenggiri, dan kembung merupakan golongan ikan scombroidae. Beberapa golongan ikan non-scombroidae juga diindikasikan mengandung histamin, yaitu mahi-mahi, sardin, dan salmon (Kim et al., 2002).

Pembentukan histamin di dalam jaringan daging ikan seiring dengan penambahan jumlah bakteri pembentuk histamin pada ikan tersebut. Semakin banyak kandungan bakteri pada ikan maka kemungkinan kandungan histamin semakin besar. Sebagian besar bakteri pembentuk histamin pada ikan berasal dari kulit, insang, dan bagian intestinal ikan sebagai normal flora.

Kemampuan bakteri untuk tumbuh dan membentuk histamin pada daging ikan sangat dipengaruhi oleh kondisi lingkungan dan media tempat tumbuh. Suhu yang optimum untuk pertumbuhan dan pembentukan histamin pada beberapa bakteri berkisar antara $25-38^{\circ} \mathrm{C}$. Pada spesies ikan yang berbeda, jenis bakteri yang membentuk histamin juga berbeda. Yoshinaga dan Frank (1982) menyatakan bahwa pada ikan cakalang (Skipjack Tuna) tidak ditemukan Morganela morganii sebagai bakteri paling banyak membentuk histamin pada beberapa ikan golongan scombroidae. Sebagian besar bakteri pembentuk histamin yang tumbuh pada skipjack tuna adalah golongan fakultatif maupun obligat anaerobik. Ini disebabkan karena setelah mengalami kematian, jaringan daging ikan bersifat anaerobik. Clostridium perfingens merupakan bakteri paling dominan membentuk histamin pada ikan tuna.

Di Indonesia kejadian keracunan yang disebabkan oleh konsumsi produk olahan ikan telah banyak terjadi walaupun kurangnya data resmi yang diperoleh tentang keracunan histamin ini. Oleh karena itu tindak lanjut penanganan keracunan histamin sangat perlu untuk mereduksi jumlah koprban yang ditimbulkan

\subsection{Tujuan dan kegunaan}

Penelitian ini dilakukan dengan tujuan untuk melihat pengaruh konsentrasi garam dan lama fermentasi terhadap kandungan histamin pada produk peda.

Kegunaan penelitian ini adalah sebagai bahan informasi bagi masyarakat tentang konsentrasi garam dan lama fermentasi yang baik digunakan dalam proses pengolahan peda dan diharapkan dapai dicapai sasaran kearah pengembangan produk peda yang bermutu.

\section{METODE PENELITIAN}

\subsection{Waktu dan tempat}

Penelitian ini dilakukan Bulan Mei 2012 di Laboratorium Pembinaan dan Penjaminan Mutu Hasil Perikanan.

\subsection{Bahan dan Alat Penelitian}

Bahan Utama dalam penelitian ini adalah ikan kembung perempuan (Rastrelliger neglectus) dan garam dapur NaCL). Bahanbahan kimia yang digunakan adalah Histamin dihydrochlorida, 4-nitrobenzen diazonium tetrafluorborate, $\mathrm{Na}_{2} \mathrm{CO}_{3} \mathrm{H} \quad{ }_{2} \mathrm{O}$, Trichloroacetic acid (TCA),n-butanol, $\mathrm{NaOH}, \mathrm{NaCL}, \mathrm{HCL}, \mathbf{n}-$ heptan,dan aquadest.

Sedangkan Alat yang digunakan adalah baskom, pisau, alat peniris, keranjang tutup, lumpang, talenan, Tampah (nyiruh), homogeniser, sentrifugator, shaker tumggal, timbangan analitik, lemari es, pompa vakum, spektrofotometer, labu takar, erlemeyer, Tabung reaksi, corong, pipet volum, kertas saring dan pipet skala serta oven.

\subsection{Metode penelitian}

Penelitian ini dilakukan dua tahap yaitu penelitian pendahuluan dan penelitian utama :

Penelitian Pendahuluan dilakukan survei lapangan untuk mengetahui cara pengolahan peda secara tradisional. Hasil penelitian pendahuluan akan dijadikan sebagai acuan penelitian utama. 


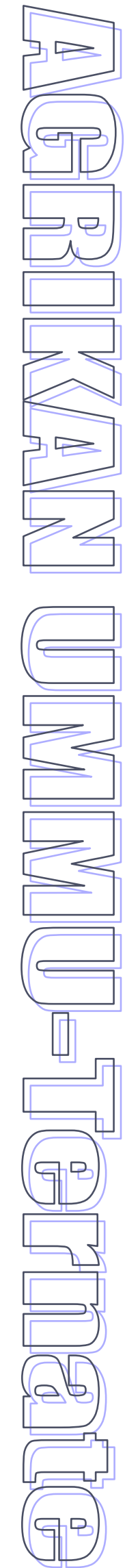

Penelitian utama dilakukan antara lain : Pembuatan produk dilaboratorium dengan metode dimodifikasi dari hasil survei lapang dan pustaka dengan perlakuan pemberian konsentrasi garam dan lama fermentasi II yang berbeda. Dan analisis kandungan histamin, kadar air dan $\mathrm{pH}$ pada produk yang dihasilkan.

\subsubsection{Perlakuan}

Penelitian ini menggunakan dua perlakuan yaitu $\mathrm{K}$ konsentrasi garam $\mathrm{A}_{1}=20 \%, \mathrm{~A}_{2}=30 \%$, waktu fermentasi yaitu $B_{1}=5$ hari, $B_{2}=7$ hari.

\subsubsection{Parameter perlakuan}

a. Analisis kandungan histamin produk

M sebanyak $1 \mathrm{ml}$ filtrat dimasukkan kedalam tabung reaksi yang ditambahkan 5 ml. n- butanol, 0,25 ml NaOH 5 mol/1, 0,75 gr NaCL. Selanjutnya dishaker/dikocok selama 10 menit.

Terbentuk dua fase dari hasil diatas yaitu fase organik dan fase asam. Diambil $5 \mathrm{ml}$ fase organik dan dimasukkan kedalam tabung reaksi, ditambahkan 2,5 ml $\mathrm{NaOH}$ 0,1 mol/1 jenuh NaCL, kemudian dilakukan pengojokan selama 1 menit dan disentrifugasi dengan kecepatan 4000 rpm selama 10 menit. Dari hasil sentrifugasi ini akan terbentuk fase organik dan fase asam.

$4 \mathrm{ml}$ fase organik dimasukkan kedalam tabung reaksi, ditambahkan 2,5 ml HCL 0,1 mol/1, 7,5 ml n-heptan. Kemudian dilakukan pengejokan selama 1 menit. Pada tahap terbentuk dua fase yaitu fase organik dan fase asam.

\section{b. Tahap analisa Histamin}

$1 \mathrm{ml}$ fase asam dimasukkan kedalam tabung reaksi dan ditambahkan $1 \mathrm{ml}$ 0,2\% nitrobenzen diazonium tetrafuoborat dan $1 \mathrm{ml}$ 10\% $\mathrm{Na}_{2} \mathrm{CO}_{3}$. Dibiarkan bereaksi selama 5 menit, selanjutnya absorbansinya diukur dengan menggunakan sprektofotometer dengan panjang gelombang $470 \mu \mathrm{m}$. Untuk mengetahui kandungan histamin dapat dihitung dengan menggunakan rumur sebagai berikut :

\section{Kadar histamin $(\mathrm{mg} / 100 \mathrm{~g})=\mathrm{Y}_{(1)(2)} \times \mathrm{FK}_{1} \times \mathrm{FK}_{2} \times \mathrm{FK}_{3}$}

Dimana :

$$
\begin{array}{ll}
\mathrm{Y}_{(2)} & : 0,0471 \mathrm{x}+0,4489 \\
\text { FK }_{1} & : \text { Faktor koreksi pada tahap preparasi }
\end{array}
$$

$\mathrm{FK}_{2}$ : Faktor koreksi tahap pemurnian

$\mathrm{FK}_{3}$ : Faktor koreksi larutan standar

c. $p H$ (Fardiaz dkk, 1989)

Bahan ditimbang seberat 10 gr, kemudian ditambah aquadest sebanyak $40 \mathrm{ml}$ atau dalam jumlah lain dengan rasio yang sama, dihomogenkan dan diukur pH-nya dengan menggunakan $\mathrm{pH}$ meter.

d. Kadar Air (AOAC, 1980)

Cawan kosong dikeringkan di oven pada suhu $105^{\circ} \mathrm{C}$ selama 30 menit, lalu didinginkan dalam cawan tersebut lalu dimasukkan ke dalam oven seberat 5 gr ke dalam oven selama 6 jam pada suhu $105^{\circ} \mathrm{C}$. Sampel dan cawan didinginkan dalam desikator lalu ditimbang.

$$
\% \text { Kadar air }=\frac{a-b}{a} \times 100 \%
$$

a : Berat sampel sebelum dioven (gr)

b : Berat sampel setelah dioven (gr)

\subsection{Analisa data}

Data yang diperoleh diolah dengan menggunakan pola Rancangan Acak Lengkap secara faktorial dengan dua kali ulangan dengan persamaan matematiknya adalah :

$$
Y_{i j k}=\mu+A_{i}+B_{j}+(A B)_{i j}+E_{i j k}
$$

dimana :

Yijk: nilai pengamatan, $\mu$ : Nilai tengah, $\mathrm{Ai}$ : pengaruh konsentrasi garam $\mathrm{ke}-\mathrm{i}(\mathrm{i}=1,2), \mathrm{Bj}$ : pengaruh lama fermentasi II $\mathrm{ke}-\mathrm{j} \quad(\mathrm{j}=\mathbf{1 , 2})$, (AB)ij: pengaruh interaksi perlakuan A ke i dan B ke-j, Eijk : pengaruh acak A ke-i, ke-j dan ulangan ke-k.

\section{HASIL DAN PEMBAHASAN}

\subsection{Penelitian pendahuluan}

Pada penelitian pendahuluan dilakukan survei lapangan salah satu industri rumah tangga, tujuan penelitian pendahukuan dilakukan untuk mengetahui proses pengolahan peda secara tradisional. Pembuatan peda tidak dilakukan setiap hari tergantung pada musim ika. Jenis ikan yang umum digunakan adalah ika Layang (Decapterus sp), ikan Kembung :Laki-laki (Rastrelliger kanagurta), Ikan Kembung 


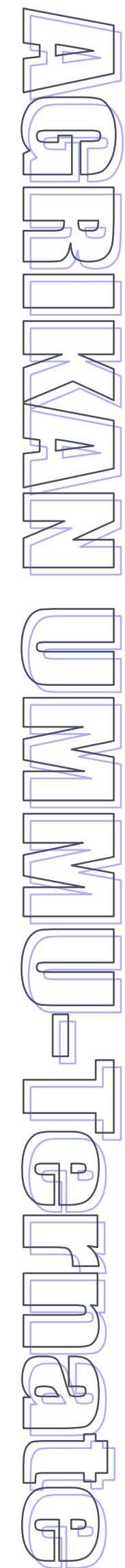

Perempuan (Rastrellinger neglectus) dan sebagainya.

Pembuatan peda secara sederhana dilakukan 6 tahap yaitu penyiangan,pencucian, penggaraman, fermentasi, penjemuran dan pengepakan.

\subsection{Penelitian Utama}

Pada penelitian utama dilakukan produk secara laboratoris dengan metode yang dimodifikasi dari survei lapang dan studi pustaka, dengan melalui tahap pensortasian, penyiangan, pencucian, penggaraman, fermentasi 1, penjemuran, fermentasi II,

penjemuran dan penyimpanan. Dalam hal ini konsentrasi dan lama fermentasi diduga memiliki pengaruh terhadap mutu produk akhir, salah satunya kadar histamin. Hal ini disebabkan karena konsentrasi garam dan lama fermentasi yang dilakukan baik secara tradisional maupun pustaka bervariasi, sedangkan pada tahap-tahap yang lain umumnya menggunakan metode dan waktu yang sama.

Pengaruh konsentrasi dan lama fermentasi II terhadap kandungan histamin peda memiliki perbedaan perlakuan yang diberikan.

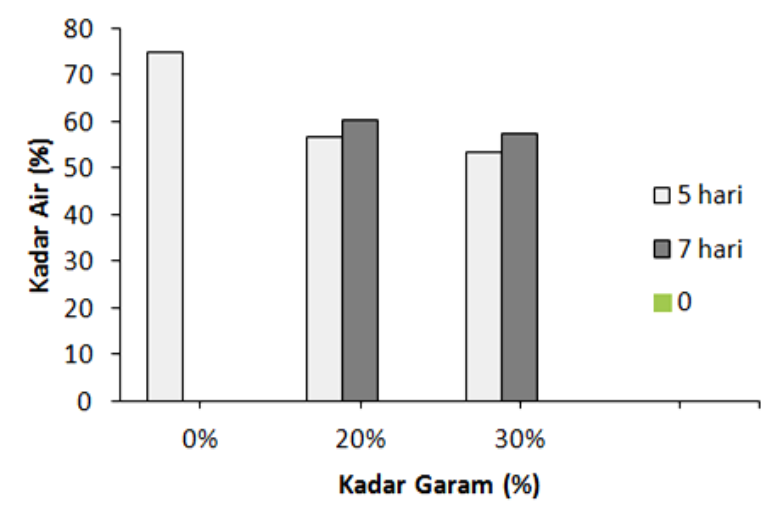

Gambar 1. Hubungan konsentrasi garam dan lama fermentasi terhadap kadar air peda

Rata-rata kadar air produk peda yang dihasilkan berkisar antara 53,44\%-60,16\%. Kadar air suatu bahan pangan sangat menentukan daya awetnya. Bahan pangan yang mengandung air bebas yang tinggi lebih muda rusak dari pada bahan pangan yang kandungan air bebasnya rendah. Air bebas gigunakan oleh mikroba untuk tumbuh dan berkembang biak pada bahan pangan tersebut. Hasil uji yang dilakukan ternyata konsentrasi garam dan lama fermentasi mempunyai pengaruh yang nyata terhadap kadar air peda yang dihasilkan pada konsentrasi $20 \%$ yaitu $54,41^{\text {a }}$ dan $30 \%$ yaitu $55,46^{\text {b }}$.

Pada konsentrasi garam $30 \%$ lebih rendah kadar airnya yaitu 53,44\% - 56,65\% dibanding pada konsentrasi garam $20 \%$ yang berkisar 57,48\% - 60,16\%. Menurut Moeljanto (1992), penggaraman dapat menghilangkan air pada permukaan tubuh ikan. Kadar garam yang semakin tinggi dapat menghilangkan air yang lebih banyak dari tubuh ikan. Hal ini disebabkan proses penggaraman akan melakukan penetrasi kedalam tubuh ikan. Garam yang masuk dalam tubuh ikan akan menggantikan air bebas yang berada dalam tubuh ikan. Menurut Rawson (1966), garam dapat mengawetkan ikan dengan cara mengeluarkan air dari tubuh ikan, air keluar dari tubuh ikan sehingga garam bisa masuk dalam tubuh untuk menggantikan air bebas, peristiwa ini terus berlangsung terus menerus berlangsung sampai terjadi suatu keseimbangan. Garam yang masuk dalam jaringan sel akan menyebabkan cairan sel menjadi larutan garam kental. Peristiwa ini dikenal sebagai peristiwa osmosis. Osmosis dapat terjadi karena dinding sel merupakan membran yang semi permiabel.

Fermentasi merupakan suatu proses penguraian senyawa-senyawa dari bahanbahan protein yang kompleks di dalam tubuh ikan menjadi senyawa-senyawa yang lebih sederhana dengan bantuan enzim yang berasal 


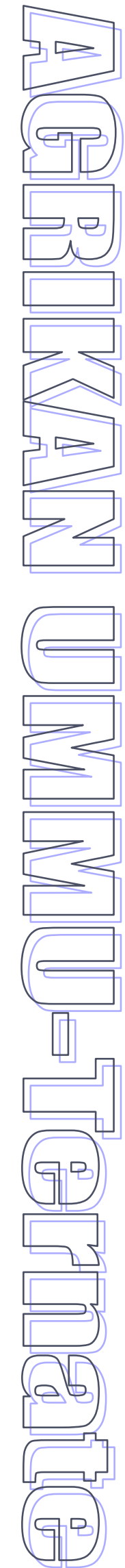

dari tubuh ikan atau dari mikroorganisme. Protein sederhana yang dihasilkan dari pemecahan protein yang kompleks inilah yang mengikat air, sehingga semakin lama fermentasi berlangsung maka kadar air dalam bahan semakin tinggi. Hal inilah yang menyebabkan kandungan air pada produk peda yang difermentasi 7 hari lebih tinggi dibandingkan fermentasi 5 hari.

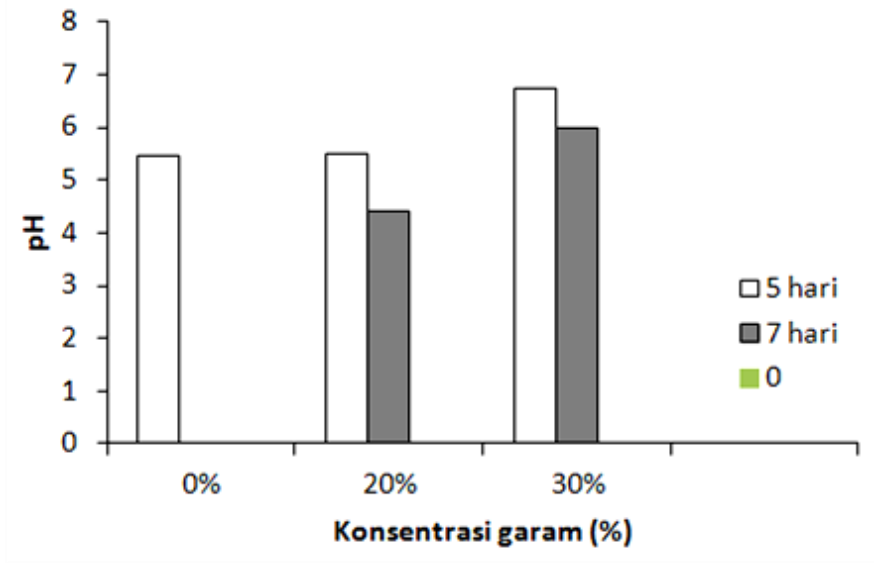

Gambar 2. Hubungan kosentrasi garam dan lama fermentasi terhadap $\mathrm{pH}$ peda

Nilai rata-rata $\mathrm{pH}$ yang dihasilkan berkisar antara 5,42 - 6,71, bahwapH peda dengan perlakuan konsentrasi garam 20\% dengan fermentasi 7 hari $(6,71)$ lebih tinggi dibandingkan $\mathrm{pH}$ peda yang mengalami perlakuan fermentasi 5 hari $(5,5)$ dan perlakuan konsentrasi garam 30\% dengan fermentasi 5 dan 7 hari.

Dari hasil analisis $\mathrm{pH}$ yang dilakukan memperlihatkan perlakuan konsentrasi garam 20\% dan lama fermentasi 7 hari mempunyai pengaruh nyata, sedangkan perlakuan konsentrasi 30\% dengan fermentasi 7 hari serta konsentrasi garam $20 \%$ juga mempunyai pengaruh yang nyata.

Konsentrasi garam 30\% dapat mencegah kenaikan $\mathrm{pH}$ yang lebih besar daripada konsentrasi garam 20\%. Sedangkan pada fermentasi 5 hari rata-rata $\mathrm{pH}$ produk dibanding dengan fermentasi 7 hari. Hal ini dijelaskan oleh Vynke (1978), kerusakan ikan akan meningkatkan pH karena terbentuk amoniak yang bersifat basa. Conel (1980) menyatakan bahwa amoniak terbentuk sebai hasil akhir dari degradasi protein, sehingga semakin banyak amoniak yang terbentuk maka $\mathrm{pH}$ akan semakin meningkat. Pendapat tersebut dikuatkan oleh Van Veen (1965), bahwa perlakuan yang kurang tepat akan menyebabkan $\mathrm{pH}$ produk meningkat. Nilai pH diatas 6,5 menandakan perlakuan yang kurang terpat. Dari hasil tersebut dapat disimpulkan bahwa fermentasi 7 hari dengan konsentrasi garam 20\% memberikan hasil yang kurang baik.

Tabel 2. Rata-rata $\mathrm{pH}$ pada peralakuan konsentrasi garam dan lama fermentasi

\begin{tabular}{ccc}
\hline Lama fermentasi (hari) & Konsentrasi $\mathbf{2 0} \%$ & Konsentrasi $\mathbf{3 0} \%$ \\
\hline 5 & 5,5 & 5,42 \\
7 & 6,71 & 6 \\
\hline
\end{tabular}

\subsection{Kadar histamin}

Rata-rata kadar histamin dari peda yang dihasilkan berkisar antara 29,65 mg/100 g tergantung jenis perlakuan yang diberikan. Nilai ini cukup tinggi bila dibandingkan dengan kadar histamin yang ijinkan oleh FDA yaitu $50 \mathrm{mg} / 100 \mathrm{gr}$.

Menurut Apriyantono (1988), salah satu faktor penyebab tingginya kadar histamin pada produk akhir adalah faktor kesegaran ikan, dimana ikan setelah mati biasanya kandungan 


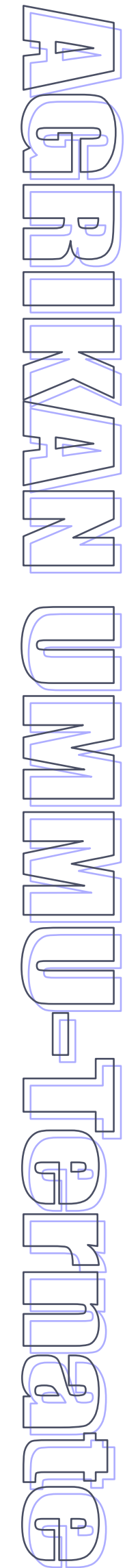

histamin meningkat karena terpecahnya asam amino histidin oleh enzim proteolitik. Dalam hal ini ikan kembung perempuan yang digunakan sebagai bahan bake peda memiliki kadar histamin 31,56 mg/100 gr. Meskipun kadar histamin bahan baku ini cukup tinggi namun belum termasuk dalam kategori yang membahayakan kesehatan manusia, dengan kata lain termasuk dalam kategori mishanding Setyaningsih dkk, 1985).

Selain karena faktor kesegaran ikan, jenis ikan juga sangat menentukan kadar histamin ikan. Ikan kembung perempuan termasuk famili Scomberesocidae, menurut Frank (1985), kandungan histamin pada ikan scombroid terutama yang sudah mulai menururn mutunya berkisar antara 10$100 \mathrm{mg} / \%$, bahkan kadang-kadang sampai $1000 \% \mathrm{mg} \%$. Hal ini juga diperjelas oleh Shifrine (1985), persyaratan bagi tingginya kadar histamin yaitu kadar histamin yang tinggi bahan asalnya.

Histamin umumnya terbentuk sebelum ikan diolah, karena menurut Gosting dan Doyle (1987), histamin sedah terbentuk ketika ikan masih mentah dan setelah pengolahan tetapada.

Adapun pengaruh konsentrasi garam dan lama fermentasi tahap II terhadap kandungan histamin peda yang dihasilkan dapat lihat Gambar 3.

Berdasarkan Gambar 3 dan hasil analisa yang dilakukan ternyata konsentrasi garam dan lama fermentasi sangat berpengaruh terhadap kadar histamin peda. Hal ini terjadi karena konsentrasi garam yang tinggi menyebabkan penetrasi garam kedalam tubuh ikan akan semakin banyak, kondisi ini diterangkan oleh Voskresenky (1965), bahwa laju penetrasi garam kedalam tubuh ikan salah satunya dipengaruhi oleh konsentrasi garam.

Menurut Zaitzev et al, (1989) konsentrasi garam sangat berpengaruh terhadap pengurangan atau pemusnahan bakteri. Hal ini disebabkan karena jumlah garam yang masuk dalam tubuh ikan sangat berperan dal;am mereduksi kadar air ikan sehingga dapat mengakibatkan aktivitas bakteri berkurang bahkan dapat membunuh spora bakteri yang memproduksi enzim histidin dekarboksilase.

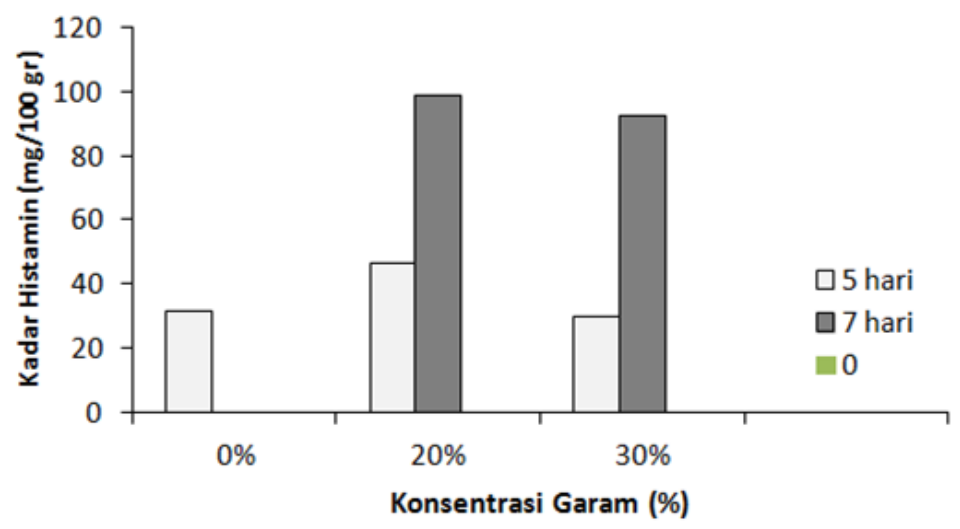

Gambar 3. Hubungan kosentrasi garam dan lama fermentasi terhadap kandungan histamin peda

Hasil analisis sidik ragam menunjukkan bahwa perlakuan lama fermentasi II sangat berpengaruh nyata terhadap kadar histamin. Dimana semakin lama fermentasi maka semakin tinggi kadar histaminnya.

Menurut Kimata (1961), terbentuknya histamin pada ikan berawal karena terjadinya kerusakan daging melalui proses autolisis. Kandungan histamin akan meningkat sejalan dengan pembusukan dan ini diduga karena pertumbuhan mikroorganisme didalam daging ikan. Bakteri yang berperan penting dalam pembentukan dan perombakan histamin adalah bakteri enteric yang menghasilkan enzim histidin dekarboksilase, diantaranya Proteus morganii, Hania sp, Klebsiella sp dan sebagainya. Aktivitas mikroba dan enzim enzim ini yang akan memecah protein menjadi asam-asam amino salah satunya histidin. Selanjutnya histidin diubah menjadi menjadi 


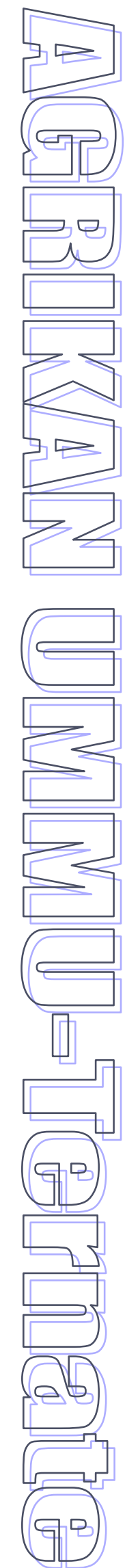

histamin oleh bakteri yang menghasilkan enzim histidin dekarboksilase. Kondisi ini dapat menjelaskan mengapa pada fermentasi 7 hari kadar histamin produk peda yang dihasilkan lebih tinggi dari kadar histamin produk peda dengan perlakuan fermentasi 5 hari.

Dari hasil uji DMRT yang dilakukan dapat dilihat bahwa perlakuan konsentrasi garam 20\% dan lama fermentasi 5 hari dan 7 hari berpengaruh nyata terhadap kadar histamin yang dihasilkan. Demikian pula halnya pada konsentrasi garam $30 \%$ dengan lama fermentasi 5 hari memperlihatkan pengaruh yang nyata terhadap kadar histamin peda, dimana kadar histamin yang dihasilkan lebih rendah dari kadar histamin dengan perlakuan konsentrasi garam $20 \%$ dengan lama fermentasi 5 hari dan 7 hari.

\section{PENUTUP}

\subsection{Kesimpulan}

Dari hasil penelitian dapat diambil kesimpulan bahwa pada kadar air, $\mathrm{pH}$ dan kadar histamin peda lebih rendah pada konsentrasi garam $30 \%$ dibanding $20 \%$, dengan lama fermentasi 7 hari memiliki kadar air, $\mathrm{pH}$ dan kadar histamin lebih tinggi dibanding fermentasi 5 hari, dan hasil terbaik pada perlakuan konsentrasi garam $30 \%$ dan lama fermentasi 5 hari dengan nilai rata-rata53,44\%, nilai pH 5,42 dan kadar histamin 29,65 mg/100gr.

Histamin dalam daging ikan dan produkproduk perikanan terbentuk akibat aktivitas enzim histidine decarboxylase yang secara endogenous terdapat pada ikan maupun oleh aktivitas bakteri histidine decarboxylase positive. Namun sebagian besar pembentukan histamin disebabkan oleh bakteri. Pada jenis ikan yang berbeda terdapat jenis bakteri penghasil histamin yang berbeda pula. Kandungan histamin selama proses penanganan dan penyimpanan produk-produk perikanan semakin meningkat apabila tidak diberikan garam konsentrasi $30 \%$ dan lama fermentasi 5 hari, karena Pada proses fermentasi, laju peningkatan kandungan histamin dapat diatasi dengan menambahkan starter bakteri asam laktat penghasil bakteriosin. Bakteri ini berfungsi sebagai kompetitor yang dapat tumbuh selama proses fermentasi dan juga menghasilkan asam laktat.

\subsection{Saran}

Perlu penelitian untuk mengetahui pengaruh waktu fermentasi tahap II yang lebih lama terhadap kadar histamin peda serta bentuk penggemasan yang lebih baik untuk produk peda.

\section{DAFTAR PUSTAKA}

Afrianto dan Liviawaty. 1989. Pengawetan dan pengolahan Ikan. Penerbit Kanisius. Jakarta.

Anonim. 1979. Ikan hasil Tangkapan Terpenting di Indonesia. Dirjen Perikanan. Departemen Pertanian. Jakarta.

Anonim. 1988. petunjuk Teknis Pengolahan Ikan Peda. Balai Bimbingan dan Pengujian Mutu Hasil Perikanan Direktorat Jenderal Perikanan. Jakarta.

Apriyantono, A. 1988. Perubahan Senyawa Bernitrogen Ikan Pindang Tongkol Selama Penyimpanan. Tesis Fakultas perikanan Pascasarjana. IPB. Bogogr.

A.O.A.C. 1980. Offical Method Analysis. $13^{\text {th }}$ edition. Ln.W.Howirt (ed), The Assosiation of Offical Analytical Chemist. Washimgton.

Fardiaz, S. 1989. Mikrobiologi Pangan. Departemen Pendidikan dan Kebudayaan, Dirjen Dikti, Pusat Antar Universitas Pangan dan Gizi. IPB. Bogor.Gosthing. D. And E. Doyle. 1987. Review of the Literature for 1986 on Food Safety and Food Borne Illness. Didalam Annual Report, food Research Institute, 1986, Departemen of Food Mikrobiology and Toxicology, Universitas of Wisconsim, Madison.

Ilyas, S. 1983. Peranan es dalam Perikanan. Direktorat Jenderal Perikanan, jakarta. 


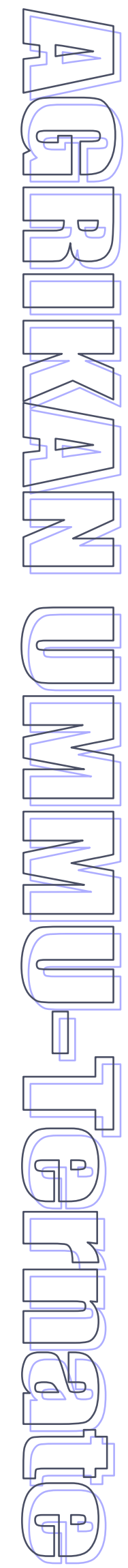

Irawan, Agus HSR. 1997. Pengawetan Ikan dan hasil Perikanan, cara mengolah dan mengawetkan Secara Tradisional dan Modern. CV. Aneka. Solo.

Kim,S.H., Price,R.J.,Morrissey,M.T., Field,K.G., Wei,C.I., and An,H. 2002. Histamine Production by Morganella morganii in Mackerel, Albacore, Mahi-mahi, and Salmon at Various Storage Temperature. J. of Food Science Vol. 67 (4)

Muchtadi. D. 1993. Toksikologi Pangan. Makalah disampaikan Pada Diklat Bidang Production Engineering by Supervisor Industri Pangan Kelompok Aneka Industri. BBIHP. Bogor.

Van Veen. 1965. Fermented and Dried Seafood Product in, South East Asia. Didalam G. Borgstrom (eds) fish as Food. Academic press. London.

Winarno, F.G. 1993. Pangan, Gizi, Teknologi dan Konsumen. PT Gramedia Pustaka Utama. Jakarta.

Yoshinaga, D.H. and Frank H.A. 1982. Histamine-Producing Bacteria in Decomposing Skipjack Tuna (Katsuwonus pelamis). Appl. Envir. Micro. Vol 44 (2).

Zaitsev, V. I. Kizevetter, L. Lacunov, T. Makarova, L. Minder and Podsevalov. 1969. Fished Curing and Processing, MIR Publisher. Moskow. 